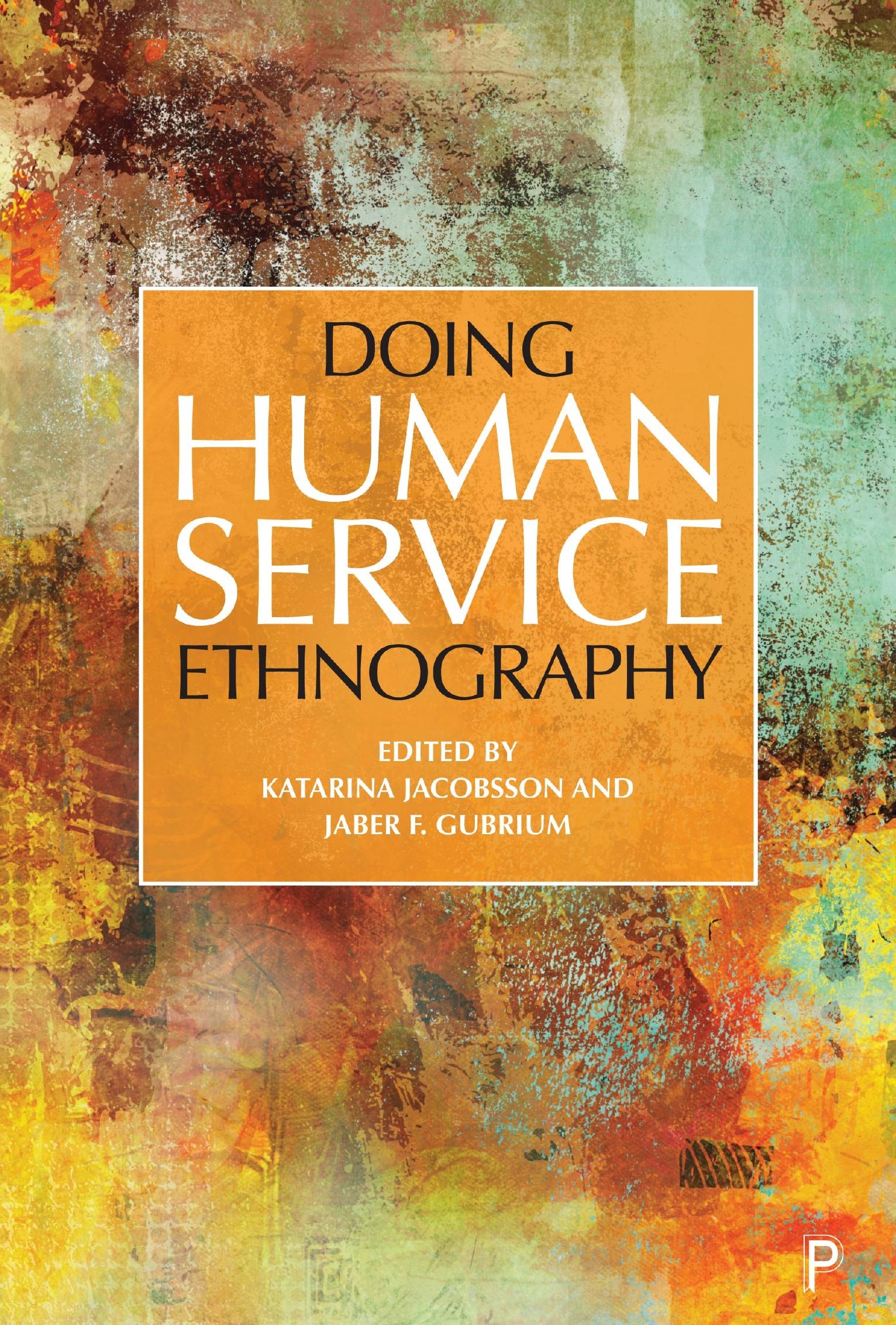




\title{
DOING HUMAN SERVICE ETHNOGRAPHY
}

\author{
Edited by \\ Katarina Jacobsson and Jaber F. Gubrium
}


First published in Great Britain in 2021 by

Policy Press, an imprint of

Bristol University Press

University of Bristol

1-9 Old Park Hill

Bristol

BS2 8BB

UK

t: +44 (0)117954 5940

e: bup-info@bristol.ac.uk

Details of international sales and distribution partners are available at policy.bristoluniversitypress.co.uk

(C) Editorial matter, selection and introduction (C) the editors. Individual chapters

(C) their respective authors, 2021

British Library Cataloguing in Publication Data

A catalogue record for this book is available from the British Library

ISBN 978-1-4473-5579-3 paperback

ISBN 978-1-4473-5581-6 OA ePub

ISBN 978-1-4473-5580-9 OA ePdf

The digital PDF and ePub versions of this title are available Open Access and distributed under the terms of the Creative Commons Attribution-NonCommercial-NoDerivatives 4.0 International license (https://creativecommons.org/licenses/by-nc-nd/4.0/) which permits reproduction and distribution for non-commercial use without further permission provided the original work is attributed.

The right of Katarina Jacobsson and Jaber F. Gubrium to be identified as editors of this work has been asserted by them in accordance with the Copyright, Designs and Patents Act 1988.

All rights reserved: no part of this publication may be reproduced, stored in a retrieval system, or transmitted in any form or by any means, electronic, mechanical, photocopying, recording, or otherwise without the prior permission of Bristol University Press.

Every reasonable effort has been made to obtain permission to reproduce copyrighted material. If, however, anyone knows of an oversight, please contact the publisher.

The statements and opinions contained within this publication are solely those of the editors and contributors and not of the University of Bristol or Bristol University Press. The University of Bristol and Bristol University Press disclaim responsibility for any injury to persons or property resulting from any material published in this publication.

Bristol University Press and Policy Press work to counter discrimination on grounds of gender, race, disability, age and sexuality.

Cover design: Robin Hawes

Cover image credit: iStock-490247468

Bristol University Press and Policy Press use environmentally responsible print partners.

Printed in Great Britain by CMP, Poole 


\section{Contents}

About the editors

Notes on contributors

Introduction: What is human service ethnography?

Jaber F. Gubrium and Katarina Jacobsson

\section{PART I Capturing professional relevance}

$1 \quad$ Shadowing care workers when they're 'doing nothing' 19 Doris Lydahl

2 Two worlds of professional relevance in a small village 35 Christel Avendal

3 Capturing the organization of emotions in child welfare decision-making Tea Torbenfeldt Bengtsson

\section{PART II Grasping empirical complexity}

$4 \quad$ Sensitizing concepts in studies of homelessness and disability 67 Nanna Mik-Meyer

5 Grasping the social life of documents in human service practice

Emilie Morwenna Whitaker

6 Debating dementia care logics

Cíntia Engel, Janaína Aredes and Annette Leibing

\section{PART III Challenges of multi-sitedness}

7 Social worlds of person-centred, multi-sited ethnography

Aleksandra Bartoszko

$8 \quad$ 'Facting' in a case of concealed pregnancy

Lucy Sheehan

9 Ethnographic challenges of fragmented human services Tarja Pösö

PART IV Noticings from ethnographic distance

10 Ethnographic discovery after fieldwork on troubled youth Malin Åkerström and David Wästerfors

11 Looking beyond the police-as-control narrative David Sausdal 
Doing Human Service Ethnography

12 Embracing lessons from ethnography in non-Western 209 prisons

Andrew M. Jefferson

Index

227 


\section{About the editors}

Jaber F. Gubrium is Professor Emeritus and former chair of sociology at the University of Missouri-Columbia, USA. He is an ethnographer and conducts research on the narrative organization of service and care in human service institutions. His interest in discursive practice, organizational embeddedness and intertextuality has been applied to the everyday contours of professional work in nursing homes, physical rehabilitation, mental health, dementia and residential treatment for emotionally disturbed children. Gubrium is co-editor of Turning Troubles into Problems (2014) and Reimagining the Human Service Relationship (2016).

Katarina Jacobsson is a sociologist and Professor of Social Work at Lund University, Sweden. With a general interest in qualitative methodology and sociology of knowledge, her current projects deal with documenting practices among human service workers, particularly within social work. Her writings on methodology deal with the analyses of documents from an ethnographic approach (for example, in D. Silverman (ed) Qualitative Research, 2021) and interviewing ('Interviewees with an agenda', with M. Åkerström in Qualitative Research, QRJ). Together with colleagues, Jacobsson published Hidden Attractions of Administration (2021). 


\section{Notes on contributors}

Malin Åkerström is Professor of Sociology at Lund University in Sweden. Her earlier ethnographic studies have concerned social control and deviance, for example, Suspicious Gifts: Bribery, Morality, and Professional Ethics (2014). She has published articles in, among other journals: Sociological Focus, Social Problems, Symbolic Interaction and Sociological Perspective. Her current research focuses on involvement and embracement in bureaucratic concerns among human service staff, and together with co-authors published Hidden Attractions of Administration (2021).

Janaína Aredes is Professor at José do Rosário Vellano University, Brazil. She holds a $\mathrm{PhD}$ in public health with an emphasis in medical anthropology from the Oswaldo Cruz Foundation and a master's in social anthropology from the Federal University of Minas Gerais, Brazil. She is a member of the research team of the Centre for Studies in Public Health and Aging/ FIOCRUZ; in the Group of Studies in Collective Health/ CNPq and the Observatory of Cultural Diversity, Brazil. As a researcher, she has experience in anthropology of the body and health, with an emphasis on the following areas: qualitative methods, life cycles, functional capacity, health education, palliative care, bioethics and medical professionalism.

Christel Avendal is a $\mathrm{PhD}$ student in social work at Lund University in Sweden. Her dissertation project is the ethnographic study Heightened everydayness: Young people in rural Sweden doing everyday life. Her previous ethnographic study was carried out in urban Ghana, looking at indigenization of social work in an African context and the integration of professional practices and the traditional extended family system. She has done ethnographic observations in various organizational settings, for example prisons, probation offices, schools, urban planning departments, youth clubs and university departments.

Aleksandra Bartoszko is a social anthropologist and associate professor at VID Specialized University in Oslo, Norway. She has researched and published on addiction, legality, risk, disability, activism and social policy, with ethnographic fieldworks in Nicaragua and Norway. Among others, she co-edited the volume The Patient: Probing the InterDisciplinary Boundaries and published an ethnographic graphic novel, The Virus, on injecting drug use and hepatitis C. She is deputy editor 
of the Journal of Extreme Anthropology. Her first monograph, Treating Heroin Addiction in Norway: The Pharmaceutical Other, is forthcoming in Routledge Studies in Health and Medical Anthropology.

Tea Torbenfeldt Bengtsson is a senior researcher at VIVE, the Danish National Centre for Social Science Research. She is a qualitative sociologist in the fields of sociology of youth, criminology and social work. Her research includes qualitative studies of social work practice and young people in locked secure care facilities, focusing on processes of marginalization and the experience of social interventions. Her current ethnographic research explores violence in young people's everyday lives and their encounters with criminal court.

Cíntia Engel is Professor at the Federal University of Bahia and a Brazilian researcher with a $\mathrm{PhD}$ in social anthropology from the University of Brasília, Brazil, and an MA in sociology from the same institution. She is one of the editors of the book Antropologias, saúde e contextos de crise (2018), which discusses ethnography, health and care problems in face of Brazilian crises. She is currently working on the subjects of dementia, geriatric and home care, and drug complexity.

Andrew M. Jefferson is a senior researcher at DIGNITY, the Danish Institute against Torture. His research focuses on prisons and prison reform in the Global South, with a particular interest in countries undergoing transition and the relationship between confinement and subjectivity. Jefferson uses the prison as an entry point for exploring the intersection between societal and personal processes. His current research includes a project on legacies of detention in Myanmar (https://legacies-of-detention.org/) and a study of quality of life in Tunisian prisons. He co-convenes the Global Prisons Research Network.

Annette Leibing is Professor of Medical Anthropology in the Faculty of Nursing at the University of Montreal, Canada. As Professor at the Institute of Psychiatry at the Federal University of Rio de Janeiro, Brazil, she founded and directed the Centro de Doenças de Alzheimer e outras Desordens Mentais na Velhice- a multidisciplinary centre for older people with mental health issues. Since then she has studied —as an anthropologist - topics related to aging: dementia, Parkinson's disease, heart disease, stem cells as technologies of hope and medications. She is currently doing research on the prevention of dementia, together with colleagues from Brazil, Germany, Canada and Switzerland. She is 
the editor of Preventing Dementia? Critical Perspectives on a New Paradigm of Preparing for Old Age (with Silke Schicktanz, 2020).

Doris Lydahl is a researcher in sociology at the University of Gothenburg, Sweden. She is interested in qualitative methods in general, and ethnography in particular. In her research she draws upon perspectives from science and technology studies. Her research is focused on issues relating to healthcare, care and medicine. She published an article on ethnography and the production of data, 'Doing data together-affective relations and mobile ethnography' in Qualitative Research (with S. Holmberg, K. Günther and J. Ranta, 2020). Lydahl is currently leading an ethnographic project on 'the values of welfare technologies'.

Nanna Mik-Meyer is Professor at Copenhagen Business School, Denmark. She is trained as an anthropologist and her areas of research are identity work in organizations, micro-sociology, qualitative methodology and processes of marginalization (the sociology of the body, disability, homelessness). She has published books with Routledge and Manchester University Press, and co-edited Qualitative Analysis (with M. Järvinen, 2020). Her works appear in journals such as Human Relations, Work, Employment and Society, Sociology of Health and Illness, Gender, Work and Organization, British Journal of Sociology and Journal of Classical Sociology, among others.

Tarja Pösö is Professor in Social Work at Tampere University, Finland. She also works as a part-time professor in the Centre for Research on Discretion and Paternalism at the University of Bergen, Norway. She has studied child protection for a number of years with a keen interest in social work practice, ethics and methodologies as well as comparative child protection research. She is one of the co-editors of Errors and Mistakes in Child Protection published by Policy Press (2020) and Adoption from Care-International Perspectives on Children's Rights, Family Preservation and State Intervention (Policy Press, 2021).

David Sausdal is a criminological ethnographer and tenure-track assistant professor of sociology at Lund University, Sweden. He is also associated with University of Copenhagen's Centre for Global Criminology, Denmark. Sausdal's research focuses on issues of transnational crime and policing-issues on which he has published in top tier criminological, sociological and anthropological outlets. Currently, one of his central interests revolves around matters of 
nostalgia and, more particularly, why many police officers nowadays express a longing for the 'good old days'.

Lucy Sheehan is a $\mathrm{PhD}$ student at Cardiff University, Wales. She is an ethnographer engaged in a humane exploration of child protection social work, with a particular interest in the methodical, collaborative practices of change talk in the context of institutional and societal requirements for self-transformation. She has a professional background in social care, including work in the voluntary and statutory sector, most recently as a social worker in child protection and substance misuse services. Alongside her PhD, Lucy teaches and works as a research associate for Cascade, and is a member of the Cardiff Ethnography, Ethnomethodology, Interaction and Talk research group.

David Wästerfors is Professor in Sociology at the Department of Sociology, Lund University, Sweden, and teaches in sociology and criminology. His research is often focused on interactions, institutions, emotions and social control. He has completed three research projects with ethnographic data from Swedish detention homes (on conflicts, schooling and violence). A related interest is qualitative methodology, shown in the book Analyze! Crafting Your Data in Qualitative Research (with Jens Rennstam, 2018). Other interests include narrative analysis, social psychology, disability studies and ethnomethodology. At the moment he is working on two projects, one on accessibility for people with disabilities in urban and digital settings, and another one on people's digital discussions and crowdsourcing activities around criminal events.

Emilie Morwenna Whitaker is a sociologist and lecturer in social policy at the University of Salford, England, and an honorary lecturer at Cardiff University, Wales. Her work is ethnographic and explores relationships between people, emotion, place and time. She has published in Qualitative Inquiry, Qualitative Research, Journal of Organizational Ethnography and the Journal of Integrated Care. 


\title{
Grasping the social life of documents in human service practice
}

\author{
Emilie Morwenna Whitaker
}

Checklists, memos, reports and other standardized forms take up much space on organizational ethnographers' desks and pervade the lives of their research respondents. Some researchers say that writing and documentation are the heartbeat of organizational ethnography (Atkinson, 2019). Yet, despite the preoccupation with documents and writing, until recently it was common to find ethnographic accounts of professional worlds that barely referred to documentation or writing practices (Atkinson and Coffey, 2004; a rare exception is Buckholdt and Gubrium, 1979). In part this has been a consequence of the predominance of studies of what has come to be called 'talk-ininteraction'. These 'talkie' ethnographies have revealed useful insights about the social production of organization and order-making in various human service sectors, including social work (for example Housley, 2000; Griffiths, 2001).

Yet, human service work of all kinds is full of documentation; it is central to the creation and maintenance of the work itself and to stabilizing local professional cultures and identities. To understand the everyday work of human service provision, we need to take seriously the routine tasks of filing, recording, assessing, form filling and case building. If we wish to understand how those organizations work and how people work in them, we must attend to their status as authors and readers of documents (Atkinson and Coffey, 2004). Research need not artificially demarcate and separate out talk-in-interaction from textual practices, because the social worlds (Strauss, 1978; Becker, 1982) of human service are constructed and maintained through both modalities - oral and textual-in tandem.

The approach informing the ethnographic research considered in this chapter is very different from approaching documents as unproblematic 
'outputs' or 'evidence' of institutional or professional practice. Rather, researchers are attending to what Prior (2003) calls the 'vitality' of forms and paperwork, alerting us to the social life of documents. Riles' (2006) edited volume, for example, brings together studies that illuminate how paperwork practices are embroiled in the circulation and production of knowledge, authority and governance (Gupta, 2012; Hull, 2012). Ethnographic work on cases and their construction points to the work documents do in actively producing practices and subjects of attention (Messick, 1993; Jacob, 2007). Alongside this is the kindred turn to materiality in the humanities, which has shed light on the practices, processes and consequences of documentation (Kafka, 2009; Kang, 2018). Collectively, such studies demonstrate that documents are not autonomous entities separate from but internal to the social or bureaucratic worlds in which they are embedded but play active roles in constructing their subjectivities and processes (Cavanaugh, 2016: Atkinson, 2017).

This chapter takes up Prior's (2003) call to attend to the vitality of documents in everyday social work practice, in this case with disabled children and their families. The chapter does not provide a guide to 'uncovering meaning' or norms inscribed within texts (compare Lester, 2009: Brodwin, 2013). It deliberately avoids the temptation to become 'bedazzled by content' (Prior, 2004, p 77). Rather, documents are treated as practical accomplishments, a sensibility not dissimilar to Garfinkel and Sacks' (1970) 'ethnomethodological indifference'. The focus is on a single documentary form-the core assessment - and follows it across a number of ethnographic episodes. The analysis identifies three distinct ethnographic approaches for studying documentation: tracing the material and graphical impact of the form itself; puzzling out practices of inscription and the work this does; and utilizing our scope for roaming to explore how people use forms in everyday interactional practices with others.

\section{The ethnographic field}

The data discussed draw upon an ethnographic study of social work practice with disabled children and their families at a time of change (Whitaker, 2015; Whitaker, 2019). The fieldwork consisted of 400 hours of observations. These included everyday activity in the team office, team meetings, management meetings, group supervisions and one staff training day. Lunch breaks were shared with team members when possible. I engaged in informal conversations in the office, attended meetings and shared car journeys to and from events. My 
observations were combined with semi-structured interviews with all staff. I collated a significant number of professional and bureaucratic texts including case files, case notes, costing and auditing forms, flowcharts, guidance notes, organizational charts and support plans. Paperwork pervaded the site. It was a ball kicked around in the mêlée of the office; to speak of it was to bond workers, critique management and to defend professional status.

Initial accounts become 'cases' as they move through statutory and professional processes. They accumulate additional textual marginalia as they move along, among them case notes, correspondence from other professionals, service reports and guidance notes. It is the creation of the paperwork, the aggregation of disparate forms-notes and documents - that identifies and denotes a topic or domain as a recognized and legitimate object of government attention and activity (Messick, 1993: Riles, 2006; Hull, 2012). This is why, almost instinctively, we balk at our documents being lost. Whether it's a planning application or joining the electoral roll, when documents are lost we are affronted not only by carelessness but by the implicit rejection that our appeal or account will not be heard.

In this team, the starting point for practice is the professional identification, documentation and justification of need. Needs must be placed into context, given a history and biography. But needs are not uncovered like stones, nor are they diagnosed through tests and lab work. Rather, in practice, they are constructed as cases are constructed. Not all needs are deemed worthy of professional attention. Some needs trigger a stronger institutional response than others. To successfully account for the identification, meeting and reporting of children's needs, social workers engage in the production of series of paperwork chains that begin with the core assessment. The core assessment record provides a structured framework for social workers to record information from a variety of sources. It is intended to provide evidence for social workers' judgments, decision-making and planning. It is one of the key sources of evidence among the multiple types of information available within such an organization (compare Gubrium and Buckholdt, 1979).

\section{Assessing need}

Core assessments were detailed, descriptive and lengthy. Descriptions of home visits and conversations with parents sat alongside correspondence from schools and health visitors. Relevant records from general practitioners and hospital consultants were noted next 
to information about household income and housing status. This collation of documentation needed to be distilled and ordered around 'The Triangle' - three domains that must be 'assessed' and recorded. These were: the developmental needs of the child; parenting capacity; and family and environmental factors. I was given examples of core assessments shortly after arriving in the field; managers thought it would help me understand the context of the work a little better. Within the office space, social workers would repeatedly centre the identification and articulation of needs as the heart of their work. They would refer to 'digging out', 'identifying' and sometimes even 'diagnosing' needs.

'Needs-talk' looped over and between the oral and textual practices of social workers as they sought to produce credible and justifiable accounts of practice. In Nancy Fraser's (1989, p 9) original formulation, needs-talk provides 'institutionalized patterns of interpretation'. It offers a framework for constructing the case while setting the parameters of institutional response. In other words, needs-talk helped to construct and classify cases. Needs-talk was capable of bestowing responsibility to 'meet needs' on the family or on the state. Needs-talk was used to evaluate the quality of relationships surrounding the child-to ask who was meeting these needs and how well, in order to form a judgment. Yet I was struggling to square the detailed, often evocative and intimate case-talk with the box-led, lengthy digital form, as the following reconstructed exchange from field notes on day 20 indicates. Amy is the social worker:

Amy: It's really important we get these core assessments right, because that's where we start to shape it all. But there are so many things to cover now, and you've got to cover them all because you can't submit the assessment unless you've written something under each section. Not everything is that relevant, and sometimes the really important stuff you have to sneak in, in a way.

EMW: So you feel you've got to shoehorn things in?

Amy: Precisely. So there's a case that has come over to us from the short-breaks teams. The core assessment looks a lot at what we call 'environmental factors' and part of that is background on the parents, including awkward things like income and education level. Well, his parents, really lovely, articulate, income-wise you'd think fine. But mum was telling me they've remortgaged and only last weekend they had a mini garage sale. They wanted to get the boy a scooter. They have spent so much money getting the 
downstairs retrofitted that they remortgaged. No help, the PCT [primary care trust] were useless. So I've found a way to get that into the assessment but it cuts across loads of the boxes. (Field notes)

The formulaic nature of the document itself, with headed boxes to complete, disrupts the conventional storied nature of professional welfare accounts (Pithouse and Atkinson, 1988; White, 2003). The core assessment begins the process of carving up family biographies into subsections and byways. It puts up lines of demarcation where in the flux of everyday life there are none. By subdividing, underscoring and classifying facets of family biography they become more orderable. It is a directed form of order-making and knowledge 'gathering' (Peckover et al, 2008; Hall et al, 2010). The whittling down of narrative and biography into more digestible chunks enables the institution to carve out specific, worker-identified 'needs' and therefore to meet them with pre-existing organizational resources. Forms render some things visible, while actively masking others, leading to professional workarounds and resistances, as Amy's account identifies. The justification for forms of this kind is that the targeted and deliberate identification of 'need' is apparently 'evidence based', whereas the narrative form of years past was mere contextual waffle (Cleaver et al, 2004). Like many organizational formats, the core assessment imposes a uniform frame on social workers' understandings, clients' narratives and other sources of information. It thus inscribes what Gubrium et al refer to as 'the descriptive demands of forms' (Gubrium et al, 1989, p 198). As Amy makes clear, the form 'shapes' the case, and demands 'completeness' so that every section is completed. At the same time, its formulaic imperatives potentially exclude what might otherwise be deemed relevant information. The documentary frame determines what shall be available and will count as 'evidence'.

\section{Inscribing need}

The following reconstructed exchange is from field notes on day 12 of observation. Megan is the social worker, who has just returned to the office after a home visit. The child in question is an autistic boy of 7 already known to social services as was his mother. Prior to Megan's visit, the family had been on the caseload of a different team, one used to supporting children with less complex family circumstances. The home visit was to follow up on a call from the school and to work up a core assessment: 
Megan: It was like a house of horrors. Carpet all threadbare; the smell; mattresses on the landing. Mum is not well, at all. She's only 36, but looks mid-50s. The place really stressed me out, dark and curtains half falling off the poles. I could do without the additional clothes wash after work tonight, already got enough piled up at home. Hey ho. Not surprised we got the call from the school, in terms of appearances it's bad. But the kids were talkative and engaging. Their sleeping arrangements were fine, weirdly, like, tidy? I think despite the younger one's autism, and mum knows about what that's likely to mean as he gets stronger; she showed me a leaflet the GP...Anyway she has booked in with the support group I checked. (Field notes)

Until Megan burst into the office with her 'house of horrors' tale, I had only encountered cases on the page, in isolation or in slivers in everyday chat. With Megan's dramatic entrance, an opportunity emerged to 'follow' the case. I arranged to meet up for lunch with her a few days after the incident. The following extract relates to the same case, in a follow-up interview:

EMW: It sounded pretty dramatic the other day, that house of horrors visit! Are you ok?

Megan: [laughs] Yes, yes I'm fine. Overreacted a bit, I think, it had been a long day and I've had a chance to speak to Helen in mental health and the two schools. Needed time to digest really, it was just, well, eerie at the time. Too much coffee maybe!

EMW: How are you going to include the home visit in the assessment? That's what the visit was about, right?

Megan: Yes. We say cores are about need and of course we are there for the child. It is their assessment, their needs. But the flipside of need is risk, isn't it? So we try to nod to the potential of that, even if we don't precisely use that language. It's a bit wishy-washy, but with a core, yes, it's about detail and description, painting a picture of family life. But with this one, we don't know really where it's going yet, so you don't want to pre-judge anything beyond that. I always make sure I use as much stuff from everybody really — school, GP, health visitor. This is just the beginning really, you don't want it to read 
as the be all and end all in case something else happens. I know that the core is like the foundation, as it were, for everything else. I'll be spending quite some time on it. Don't get me wrong though, if I thought those kids were at risk cos mum was unstable or the house was actually unsafe, they'd be out of there. I just don't think that's the case here. (Field notes)

In our conversation, Megan is highlighting the artfulness of constructing a case. She takes a notable step back from the 'house of horrors' tale she entered the office with, while underscoring her credibility in identifying risk and protecting the child's interest. She hints at the importance of ambiguity in completing some elements of the core assessment: "It's a bit wishy-washy...yes, it's about detail and description, painting a picture of family life. But with this one, we don't know really where it's going yet, so you don't want to prejudge anything". This scope for ambiguity was borne out in the core assessment document which she shared with me a fortnight later, as the following extract indicates.

I have concerns about cleanliness of the property-cat detritus was found upstairs, there was a lack of proper sleeping arrangements for Miss X-a mattresses on the floor was found which Miss X said was a temporary fix for her until a new bed arrived. The house does need some care and attention, so I am recommending our in-house domestic team coordinate with the housing team to do a deep clean and tidy. Miss X would benefit from extra support so I have referred her back to her GP and to the local autism network. (Extract from Section 17 Core Assessment)

In the written assessment, the evocative and sensorial 'house of horrors' descriptors were reworked. In the core assessment, social workers were tasked with providing accounts and making judgments they knew would inform future prescriptions for action. Had the 'house of horrors' been written as such, with cat faeces documented forensically, dirty mattresses mapped, a picture of chaos painted, the trajectory for this case would likely turn from one concerned with 'need' to one of 'neglect'. Most obviously what is written has significant consequences for the child and family. What needs are demarcated will influence what services and support are provided. What context is given will firm up the 'official' view of the family, what the institution 'thinks' 
about them. As such, the core assessment helps to construct and firm up the subject at hand - this is a competent parent or a vulnerable parent or a risky parent. Official documents are accounts that make things happen in the world: the sifting of entitlement claims; the inscribing of subjectivity; and the 'laying of foundations' for future action.

\section{Following the form}

The second ethnographic strategy concerns the mobility of the record, as it travels in organizational space and time, as does the ethnographer herself. Documents enable institutions to act over time and space, to collapse and expand both. The completion of an assessment and its bureaucratic representation condense the temporal dimensions of the client's problems, but render the account available for future inspection. The forms reorder the present and immediate past while projecting possible organizational futures. Megan was tasked with constructing a case in the present, utilizing accounts and evidence from the near past. The assessment would have future consequences dependent on the account provided in the present. In her own words, because "we don't know really where it's going yet", the door needed to be kept open to alternative possibilities, at least for a while, lest the case be "pre-judged" and set on a very different path. The function of the document is to present past action to future inspection, while also being conscious that the prescription makes it possible in future to refer to what was agreed in the past. The effect of the form, meanwhile, is to synchronize, to make the different times (and spaces) equivalent. (See Gubrium et al, 1989 on the chronotypes of organizational forms and records.)

Further, the document reinforces the abstraction which distinguishes written from oral communication (Goody, 1977; Cicourel, 1985). In most instances of oral communication, we have a specific sense of who we are speaking to-we can call this a 'case sense'. Written communication, because it is made over time and at a distance, is more often made in general terms, and directed at an unknown readerconstructed in a 'category sense'. Megan's tempered phraseology is written within the register of a category sense. The core assessment, once written, enables unknown others to take it up, to pass it along, to make it more of a fact, while aligning it firmly with the author's ownership and judgment (compare Latour and Woolgar, 1979: Latour, 1987). The core assessment turns the local production of knowledge into an artifact that can be loosened from its local context. As such, writing allows specific forms of knowledge to become 'mobile'. It is the combined immutability and mobility of these inscriptions that 
render them peculiarly functional, while multiplying their effects for professionals and families.

In attending to paperwork as actively constructed, mutable and mobile we are jolted out of easy presumptions that these are finished, static and representative things. By following paperwork, we are confronted with chains of relations, power and discourses invoked and constructed on the page. They provide written accounts of justification and (in)action while at the same time constructing the very subjects of that justification. Paperwork 'makes the case' in both senses of the term (Atkinson, 1995). Documents, case notes and audits coexist in alliances that reconstitute agency and interactivity. The file, thus, does not just report and represent. It also involves and constitutes an extended nexus of those present and absent.

\section{Contesting need}

The third ethnographic perspective turns to the practical use of documentary materials. Documentary sources, like the core assessment, feature prominently in social workers' professional meetings. Such records, as we have seen, constitute the 'evidence' that can be consulted in order to establish the facticity of events and to justify particular interpretations.

In much professional human service work there is a symbiotic relationship between meetings and documents. Entire ceremonies can be devised to assess professional practice through a forensic examination of case paperwork (Housley, 2000; Whitaker, 2019; Whitaker and Atkinson, 2019). Case assessments are pored over in supervisions, discussed and contested between team members, referred to in multi-agency meetings. Documents do not remain sealed in folders-digital or otherwise. They become ripe for rereading in utterly different contexts serving different ends. Documents regularly find new audiences at meetings (Freeman, 2008; Whitaker, 2019). They may be circulated in advance, proffered as an example, slammed down in frustration. Meetings, like documents, are also aimed at future actions: they are 'symbolic encodings' (Weick, 1995) which enables them to be used or acted upon by others, later, elsewhere, 'at a distance'. Paperwork can be dusted off and redeployed when a challenge is made. It has a role in interpersonal and embodied interaction. It very much 'gets off the shelf'.

The following extract is taken from my research diary. In it I reflect on a meeting wherein the core assessment was used as 'evidence' to contest need. This meeting was a regular institutional event; ordinarily 
between 8 and 10 team leaders and managers would attend. This particular instance referred to a case of twin boys:

Major drama at the meeting today. Team leader incandescent after a parent requested a review of her support. Parent writes a private letter that was so intimate and personal it must have taken real courage to send. I can't believe it was read out, I just can't. Then to dig out the core assessment as though it was an arbiter of truth, when its 2 years old, flipping through it like a school report. The most awkward and upsetting thing I've been party to so far. There was something in the tone of the reading that implied the idea of 'not wanting to parent'. (Research diary)

The 'major drama' began with a letter from the parent. In the meeting, the team leader took to her feet to read it to the assembled staff. The parent had written to complain about the 'bureaucratic nightmare' of the system as she tried to support twin boys with complex support needs. In it she asked for additional support and an urgent review of their support plan. I made an ethical decision not to explicate the specific contents of the letter in my field notes, my thesis or elsewhere.

After the letter was read, the manager concluded with:

'You know, you're her mother! I'd do that for my child! I would expect families to be doing that for their children. What do you want me to do?! We've created this sort of extraordinary expectation I think.' (Research diary)

"I'd do that for my child" was a reference to the requirement that every four hours one of the boys had to take a variety of medicines for different problems. The mother was struggling to do this on her own. She was tired. She was struggling to cope. She felt that a review was needed urgently. She was seeking overnight support from the sleep service and 'an extra pair of hands'.

Next, the team manager brought out the core assessment. Or rather, she raised it from the table in front of her and proceeded to treat it as a prop for a sermon. For all the high drama, this moment was clearly planned. She continued, flipping the pages as she went: "The core assessment 'does not identify any needs associated with mum's ability to parent.". She turned the page, "The home was 'smart, kept well, clean and ordered." "The family support network was 'small but 
local." Silence was propped up by supportive knowing nods from those present.

The mother's letter was met with incredulity, and her moral standing as a parent was called into question. The construction on paper was of someone 'coping', and here was someone in her own words 'not coping'. Paperwork shapes and stabilizes subjectivities from the perspective of the organization; this contestation challenged that. Documents are also 'part of the way in which the organisation talks to itself... [and] about itself' (Harper, 1997, p 129) (emphasis in original). The organizational warrants for intervention are destabilized when the accuracy of its own accounts of sense-making are troubled.

The document does not compete with face-to-face interaction, but anchors and frames it. In this process, social work texts and social work talk are transformed, producing a new situation that cannot be reduced to any simple combination of either the text itself or practice without text. The ethnographic design holds both in tension by moving back and forth between the inside and outside of specific episodes, tracing and tracking their origins and futures (Clifford, 1983). This is an important methodological point. This moment of workplace drama encourages us to think about practices of unfolding, making and contestation. Organizational life is series of continuous, situated and contingent processes geared to defining and stabilizing the present situation (Altheide, 2000). Ethnographic work enables forms, cases and people to be followed as part of the micro-politics of organizational life. There is a rhythm and flow to the episodic nature of ethnographic work as there is to organizational life.

Ethnographic work draws attention to the context of speech and writing acts. The competent social worker is a 'stressed out' (not 'burnt out') social worker, like Megan returning from her 'house of horrors'. The credible team manager is one who valiantly stands by the organizational account in meetings, but concedes to a review in private. What is significant is that stress or incredulity is not hidden but carefully displayed. That Megan referred to a 'house of horrors' and her stress in talk and not in print is less about the accuracy of that descriptor and more about the work that phrase is doing. Her talk shores up a sense of professional identity and competency; she is confirming to another who 'we' are and what we 'go through' and how that makes 'us' special and distinctive from others.

I was only able to spot the local potency of needs-talk as a discursive repertoire of how the organization talks to itself because I kept bumping into it in the course of my fieldwork. I followed it across modalities 
of talk and text into management meetings, along car journeys and over coffees. Had I encountered any of these episodes in isolation, it is unlikely I would have identified the importance of it as a prism for thrashing out micro-sociological dramas about how accounts become claimed, validated or rejected.

\section{Conclusion}

Ethnographic work can do things with documents that other methodologies struggle to do. Three have been identified here. Firstly, we can trace the material and graphical impact of the form itself. This was important in order to establish institutionally granted parameters of knowledge and action. They provide a directed form of order-making and knowledge 'gathering', whittling down complexity into more digestible chunks. Workers could find workarounds to this directive-Amy found creative ways to 're-storify' her case work. The form 'shapes' the case, and demands 'completeness' so that every section is completed. At the same time, its formulaic imperatives potentially exclude what might otherwise be deemed relevant information. Secondly, the ethnographer can analyse forms for various kinds of inscription. Inscription does not only refer to content. Analyzing inscription also requires identifying forms of address (is this document inscribing a 'case' or 'category' sense), mapping the range of potential audiences and routes through which documents flow and plotting what the potential consequences of that trajectory will be. The ethnographer can follow the life course of a document in close to real time, and can attend to the settings it arrives in. An ethnographic take on practices of inscription involves attending to how a given document becomes mutable and mobile, what its career might be. Finally, the third ethnographic approach focuses on how people use forms in everyday interactional practices and how they leverage ethical and professional dilemmas with and through documentation. This is explicated in the case of the twins. Here, the ethnographer is drawing attention to the intimacies between talk and text in organizational settings.

The rich fruits of ethnographic fieldwork-field notes, naturally occurring talk, interview data and extracts from documents - speak to the richness that ethnographic work generates in terms of our 'own' writing. Insightful conversations about practice, informal quips about colleagues and the observation of the grind of paperwork materialized because we were undertaking immersive ethnographic fieldwork. As we observe and write and follow up and observe and write, the 
imperceptible and iterative loops of description/analysis help us to align with the rhythms of our fields. Noticings and events duly find their way written up as notes or memos, considered in diaries, drawn as maps to be picked up and reworked later. In-situ and post-hoc writing help to firm up an understanding of what was going on as it occurred and unfolded (Atkinson, 2019).

Ethnographers have the luxury of going back and asking questions, seeking out examples or clarification and finding another case to follow. The iterative and multimodal nature of ethnographic work (talk, text, embodied interaction, observation) helped me to 'see' the field in infrastructural and architectural terms. This was important in order to understand indigenous modes for making sense of the work, in this place at this time. Quips and frustrations mentioned in passing in a corridor helped to shore up important aspects of the context of the place and work. My gradual familiarization with team members meant that asking to see an example of an assessment or a form was not an imposition. Over time they would proffer examples without request, and I too built up a healthy pile of paperwork. I read files, took notes and asked questions in real time. Cases were discussed and debated as part of the natural ebb and flow of the setting, illuminating the challenges of contemporary social work practice with children and families. I began to understand the registers team members used to persuade and cajole in the process of case building. I could plot the institutional enclosures and regimes through which they and the families they worked with had to pass.

The document itself is a practised thing: more akin to a corridor than an arrow, it is something through which other things flow. It plays an important part in constituting social realities and coordinating activity. It is contingent, because it could always have been otherwise, and is produced through what Dorothy Smith (2002, p 3) calls 'back and forth work' among and between writers and readers, authors and editors. This is evident in the 'working up' of the case assessment. Ideas, suggestions, frustrations and characterizations were tried on and tried out in talk before being stabilized temporarily in print. Yet, an interview alone would not reveal the number of hands involved and iterations made before an account is encoded in text. It would miss the 'house of horrors' tale and its artful reworking. Equally, being handed a pile of core assessments to 'read' would mask the contestations, deliberations and real skill that lay behind the text. Reading case files in isolation would not reveal the degree of self-referential work involved in paperwork. Such a strategy would fail to notice how 
discursive formations trail between paperwork and interaction, and how tropes found in one are carried over into other contexts and settings. An ethnographic approach to paperwork involves following these documents as they travel across the site, asking how, where and by whom they are produced, edited, revised or filed. By following a documentary career across a number of episodes, the suppleness and potency of paperwork reveals itself. Instead of asking what documentary practices produce in terms of rationality and coherence, ethnographic attention revels in their indeterminacies, conditions and possibilities. It can stumble across that which goes unwritten but said, ending up slammed on desks or read like a sermon.

\section{References}

Altheide, D.L. (2000) 'Identity and the definition of the situation in a mass-mediated context', Symbolic interaction, 23(1): 1-27.

Atkinson, P. (1995) Medical Talk and Medical Work, London: Sage.

Atkinson, P. (2017) Thinking Ethnographically, London: Sage.

Atkinson, P. (2019) Writing Ethnographically, London: Sage.

Atkinson, P. and Coffey, A. (2004) 'Analysing documentary realities', in D. Silverman (ed) Qualitative Research: Theory, Method and Practice, London: Sage, pp 77-92.

Becker, H.S. (1982) Art Worlds, updated reprint. Berkeley, CA: University of California Press, 2008.

Brodwin, P. (2013) Everyday Ethics: Voices from the Front Line of Community Psychiatry, Berkeley, CA: University of California Press.

Buckholdt, D.R. and Gubrium, J.F. (1979) Caretakers: Treating Emotionally Disturbed Children, Thousand Oaks, CA: Sage.

Cavanaugh, J.R. (2016) 'Documenting subjects: Performativity and audit culture in food production in northern Italy', American Ethnologist, 43(4): 691-703.

Cicourel, A. (1985) 'Text and discourse', Annual Review of Anthropology, 14: 159-185.

Cleaver, H., Barnes, J., Bliss, D. and Cleaver, D. (2004) Developing Information Sharing and Assessment Systems, London: Department for Education and Skills.

Clifford, J. (1983) 'On ethnographic authority', Representations, 2(1): 118-145.

Fraser, N. (1989) Unruly Practices: Power, Discourse, and Gender in Contemporary Social Theory, Minneapolis, MN: University of Minnesota Press.

Freeman, R. (2008) 'Learning by meeting', Critical Policy Analysis, 2(1): 1-24. 
Garfinkel, H. and Sacks, H. (1970) 'On formal structures of practical actions', in J.C. McKinney and E.A. Tiryakian (eds) Theoretical Sociology: Perspectives and Developments, New York: Appleton Century Crofts, pp 338-366.

Goody, J. (1977) The Domestication of the Savage Mind, Cambridge: Cambridge University Press.

Griffiths, L. (2001) 'Categorising to exclude: The discursive construction of cases in community mental health teams', Sociology of Health and Illness, 22(4): 453-476.

Gubrium, J.F. and Buckholdt, D.R. (1979) 'Production of hard data in human service institutions', Pacific Sociological Review, 22(1): 115-136.

Gubrium, J.F., Buckholdt, D.R. and Lynott, R.J. (1989) 'The descriptive tyranny of forms', in J.A. Holstein and G. Miller (eds) Perspectives on Social Problems: A Research Annual, Greenwich, CT: JAI Press, pp 195-214.

Gupta, A. (2012) Red Tape: Bureaucracy, Structural Violence, and Poverty in India, Durham, NC: Duke University Press.

Hall, C., Parton, N., Peckover, S. and White, S. (2010) 'Childcentric information and communication technology (ICT) and the fragmentation of child welfare practice in England', Journal of Social Policy, 39: 393-413.

Harper, R. (1997) Inside the IMF: An Ethnography of Documents, Technology and Organizational Action, San Diego, CA: Academic Press.

Housley, W. (2000) 'Story, narrative and team work', The Sociological Review, 48(3): 435-443.

Hull, M. (2012) Government of Paper: The Materiality of Bureaucracy in Urban Pakistan, Berkeley, CA: University of California Press.

Jacob, M.A. (2007) 'Form-made persons: Consent forms as consent's blind spot', PoLaR:Political and Legal Anthropology Review, 30(2): 249-268.

Kafka, B. (2009) 'Paperwork: The state of the discipline', Book History, 12: 340-353.

Kang, H.Y. (2018) 'Law's materiality', in A. PhilippopoulosMihalopoulos (ed) Routledge Handbook of Law and Theory, London: Routledge, pp 453-474.

Latour, B. (1987) Science in Action, Cambridge, MA: Harvard University Press.

Latour, B. and S. Woolgar (1979) Laboratory Life: The Construction of Scientific Facts (2nd edn), reprint, Princeton, NJ: Princeton University Press, 1986. 
Lester, R. (2009) 'Brokering authenticity: Borderline personality disorder and the ethics of care in an American eating disorder clinic', Current Anthropology, 50(3): 281-302.

Messick, B. (1993) The Calligraphic State: Textual Domination and History in a Muslim Society, Berkeley, CA: University of California Press.

Miller, G. (1994) 'Toward ethnographies of institutional discourse', Journal of Contemporary Ethnography, 23(3): 280-306.

Peckover, S., White, S. and Hall, C. (2008) 'Making and managing electronic children: E-assessment in child welfare', Information, Communication and Society, 11(3): 275-294.

Pithouse, A. (1987) Social Work: The Social Organisation of an Invisible Trade, Aldershot: Avebury Gower.

Pithouse, A. and Atkinson, P. (1988) 'Telling the case: Occupational narrative in a social work office', in N. Coupland (ed) Styles of Discourse, Beckenham: Croom Helm, pp 183-200.

Pithouse, A., Hall, C., Peckover, S. and White, S. (2009) 'A tale of 2 CAFs: The impact of the electronic Common Assessment Framework', British Journal of Social Work, 39(4): 599-612.

Prior, L. (2003) Using Documents in Social Research, London: Sage.

Prior, L. (2004) 'Doing things with documents', in D. Silverman (ed) Qualitative Research: Theory, Method and Practice (vol 2), London: Sage.

Riles, A. (2006) Documents: Artifacts of Modern Knowledge, Ann Arbor, MI: University of Michigan Press.

Smith, D.E. (2002) Texts, Facts and Femininity: Exploring the Relations of Ruling, New York: Routledge.

Strauss, A. (1978) 'A social world perspective', in N.K. Denzin (ed) Studies in Symbolic Interaction (vol 1), Greenwich, CT: JAI Press, pp 119-128.

Weick, K.E. (1995) Sensemaking in Organizations, Thousand Oaks, CA: Sage.

Whitaker, E.M. (2015) 'Personalisation in children's social work: From family support to "the child" budget', Journal of Integrated Care, 23(5): 277-286.

Whitaker, E.M. (2019) “"Bring yourself to work”: Rewriting the feeling rules in "personalized" social work', Journal of Organizational Ethnography, 8(3): 325-338.

Whitaker, E.M. and Atkinson, P. (2019) 'Authenticity and the interview: A positive response to a radical critique', Qualitative Research, 19(6): 619-634. 
White, S. (2003) 'The social worker as moral judge: Blame, responsibility and case formulation', in C. Hall, K. Juhila, N. Parton and T. Pösö (eds) Constructing Clienthood in Social Work and Human Services, London: Jessica Kingsley, pp 177-192. 
"In this time of pandemics and apparently faceless global corporations, human service work is fundamentally important to all our lives. In this fascinating volume, two leading experts in the field bring together an array of insightful accounts of how service encounters work in the field. An essential book for anybody wanting to engage with the ethnographic realities of practitioner-client interaction."

David Silverman, Goldsmiths, University of London

EPDF and EPUB available Open Access under CC-BY-NC-ND licence.

Human service work is performed in many places - hospitals, shelters, households, prisons, schools, clinics - and is characterized by a complex mixture of organizing principles, relations and rules. Using ethnographic methods, researchers can investigate these site-specific complexities, providing multi-dimensional and compelling analyses.

Bringing together both theoretical and practical material, this book shows researchers how ethnography can be carried out within human service settings. It provides an invaluable guide on how to apply ethnographic creativeness and offers a more humanistic and context-sensitive approach in the field of health and social care to generating valid knowledge about today's service work.

Katarina Jacobsson is Professor of Social Work at Lund University, Sweden.

Jaber F. Gubrium is Professor Emeritus of Sociology at the University of Missouri, USA. 